\title{
The vascularization paradox of non-union formation
}

\author{
Maximilian M. Menger ${ }^{1,2} \mathbb{D} \cdot$ Matthias W. Laschke ${ }^{2} \cdot$ Andreas K. Nussler $^{1,3} \cdot$ Michael D. Menger $^{2} \cdot$ Tina Histing $^{1}$
}

Received: 24 July 2021 / Accepted: 21 November 2021 / Published online: 14 February 2022

(c) The Author(s) 2022

\begin{abstract}
Despite major research efforts to elucidate mechanisms of non-union formation, failed fracture healing remains a common complication in orthopedic surgery. Adequate vascularization has been recognized as a crucial factor for successful bone regeneration, as newly formed microvessels guarantee the supply of the callus tissue with vital oxygen, nutrients, and growth factors. Accordingly, a vast number of preclinical studies have focused on the development of vascularization strategies to stimulate fracture repair. However, recent evidence suggests that stimulation of blood vessel formation is an oversimplified approach to support bone regeneration. This review discusses the role of vascularization during bone regeneration and delineates a phenomenon, for which we coin the term "the vascularization paradox of non-union-formation". This view is based on the results of a variety of experimental studies that suggest that the callus tissue of non-unions is indeed densely vascularized and that pro-angiogenic mediators, such as vascular endothelial growth factor, are sufficiently expressed at the facture site. By gaining further insights into the molecular and cellular basis of non-union vascularization, it may be possible to develop more optimized treatment approaches or even prevent the non-union formation in the future.
\end{abstract}

Keywords Non-union $\cdot$ Vascularization $\cdot$ Angiogenesis $\cdot$ Bone healing $\cdot$ VEGF $\cdot$ Bone healing

\section{Introduction}

Despite impressive progress in our understanding of the mechanisms of delayed healing and non-union formation, failed fracture healing still represents a major clinical challenge. Non-unions are defined by the U.S. Federal Drug Administration as "failure to achieve union by 9 months since the injury, and for which there has been no signs of healing for 3 months' [1]. However, others define non-union formation in long bones after a period of 6 months with no radiological sign of fracture healing [2]. In general, the diagnosis of non-union should include both the clinical and radiological examination of the patient [3].

Maximilian M. Menger

maximilian.menger@uks.eu

1 Department of Trauma and Reconstructive Surgery, BG Trauma Center Tuebingen, Eberhard Karls University Tuebingen, 72076 Tuebingen, Germany

2 Institute for Clinical \& Experimental Surgery, Saarland University, 66421 Homburg/Saar, Germany

3 Department of Trauma and Reconstructive Surgery, BG Trauma Center Tuebingen, Siegfried Weller Institute for Trauma Research, Eberhard Karls University Tuebingen, 72076 Tuebingen, Germany
Large segmental bone defects, infections, tumors, and systemic comorbidities as well as mechanical instabilities associated with insufficient osteosynthesis bear a high risk of non-union formation [4-7]. However, in many cases, the cause of fracture healing failure is unclear, and thus, effective treatment strategies are lacking. Accordingly, the failure rate of fracture healing is still up to 10\% [8]. Furthermore, non-unions do not only result in significant pain and loss of function with subsequent reduction of quality of life, but additionally cause a substantial economic burden on the health care system [9].

Bone regeneration involves multiple biological and biochemical processes. Among these, vascularization is supposed to be essential for successful fracture healing $[10,11]$. Bone is a highly vascularized tissue, which crucially depends on the close spatial and temporal interaction between blood vessels and osteogenic cells to maintain bone development and remodeling [12]. During bone repair, the skeletal vasculature provides vital cells, hormones, and nutrients to the fracture site to allow for callus remodeling from avascular cartilaginous tissue toward mineralized woven bone [13]. Therefore, a considerable number of studies have focused on the application of vascularization strategies to prevent or treat non-union formation. These strategies involve (i) 
biophysical applications, (ii) systemic pharmacological interventions, and (iii) tissue engineering, including the development of sophisticated scaffold materials, local growth factor delivery systems, cell-based techniques, and surgical vascularization approaches [10].

However, there is evidence that vascularization is only one piece of the puzzle in the much more complex process of bone regeneration. Hence, this review compares and discusses the current literature focusing on the role of vascularization within the complex scenario of bone regeneration, elucidating both, supportive and inhibitory actions of the blood vessel formation on the healing outcome.

\section{The role of vascularization in bone regeneration}

The skeletal vasculature is important for bone development and remodeling as well as for bone regeneration $[14,15]$. Previous studies using dye injections and radiomicropraphs for the visualization of blood vessels have provided important fundamental data on the organization of the bone vasculature, particularly in long tubular bones $[16,17]$. More recently, a plentitude of technological advancements in immunohistochemical and diagnostic imaging techniques, such as cell type-specific markers as well as confocal or two-photon microscopy and microcomputed tomography $(\mu \mathrm{CT})$ with three-dimensional imaging reconstruction, have markedly improved our understanding of the morphology and specialized functions of the bone vasculature [18-21].

Similar to other tissues, the vasculature of long bones exhibits a strongly hierarchical architecture with an arterial branch feeding a dense network of capillaries, which drains in venules coalescing into a large vein within the center of the diaphysis [19]. Interestingly, capillaries in bone tissue can be distinguished by their anatomical localization and immunohistochemical markers. Type $\mathrm{H}$ capillaries are organized as vessel columns and can be found in the metaphysis, where they express high levels of the junctional protein CD31 and the sialoglycoprotein endomucin (Emcn) [22]. Type L capillaries form a dense, highly branched capillary network in the bone marrow cavity of the metaphysis. These types of capillaries express only low levels of CD31 and Emcn (Fig. 1). Of note, type $\mathrm{H}$ and L capillaries are interconnected to a morphological and functional unit,

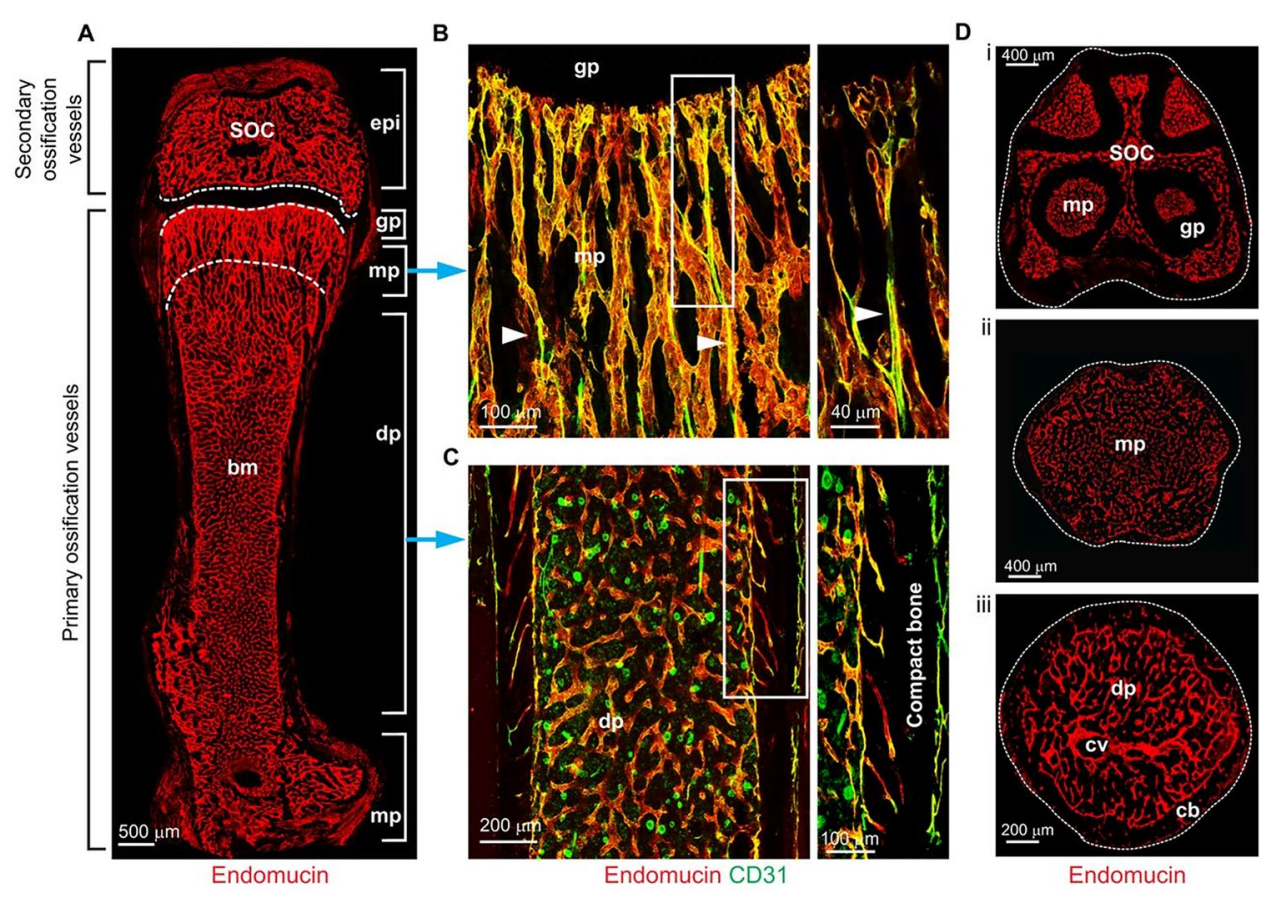

Fig. 1 Architecture of the long bone vasculature according to Sivaraj et al. [22]. A Confocal image of endomucin (Emcn)-immunostained (red) endothelium in a $100 \mu \mathrm{m}$-thick section of P21 murine femur. Regional differences in the organization of the vasculature are evident, as highlighted in the higher magnification images $(\mathbf{B}, \mathbf{C})$ of the regions marked by blue arrows. B In the metaphysis, type $\mathrm{H}$ vessels (CD31 ${ }^{\text {high }}$ Emcn $^{\text {high }}$ ) exhibit a columnar organization and arterial connections (arrowheads); the panel on the right shows a higher magnification of the boxed region. $\mathbf{C}$ In the diaphysis, highly branched sinu- soidal type $\mathrm{L}$ capillaries $\left(\mathrm{CD} 31^{\text {low }} \mathrm{Emcn}^{\text {low }}\right)$ are found; these connect to endosteal type $\mathrm{H}$ vessels in the proximity of compact bone. D Confocal images of transverse sections through a P21 femur in the region of the growth plate (i), metaphysis (ii), and diaphysis (iii). SOC secondary ossification center, epi epiphysis, $b m$ bone marrow cavity, $g p$ growth plate, $m p$ metaphysis, $d p$ diaphysis, $c v$ central vein, $c b$ cortical bone (Reprinted with permission of The Company of Biologists: [Development], [22] copyright (2016)) 
providing a sufficient blood supply for bone development and metabolism [22].

Ten to $15 \%$ of the total cardiac output supplies the skeletal vascular system [23], providing the surrounding tissue with adequate amounts of oxygen and nutrients as well as hormones, growth factors and neurotransmitters, such as the brain-derived serotonin [24]. The importance of the bone vasculature into maintaining the bone cells' survival and activity is illustrated in skeletal diseases, such as craniofacial dysmorphology [25] and idiopathic osteonecrosis [26]. These diseases are caused by insufficient angiogenesis during skeleton development or by an inadequate vascular function within matured bone.

Trauma to the musculoskeletal system induces a disruption of the vital vascular network, resulting in acute hypoxia and necrosis of the surrounding bone tissue [27]. The inflammatory response, which is mainly mediated by macrophages and granulocytes, recruits mesenchymal and osteoprogenitor cells to the fracture site [28, 29] (Fig. 2). These cells infiltrate the callus area through sprouting capillaries originating from the endosteum and bone marrow $[12,30]$. Following the establishment of a stable callus tissue within the fracture zone, a remodeling cascade is initiated, in which osteoclastic removal of excessive bone tissue and associated angiogenesis leads to the development of mature lamellar bone [12]. Subsequently, the original bone morphology and the vascular supply is restored. A plenitude of mediators and cytokines is involved in this healing and remodeling process, including bone morphogenetic protein (BMP)-2 and BMP-4 [31, 32], basic fibroblast growth factor (bFGF) [33], transforming growth factor (TGF)- $\beta$ [34], platelet-derived growth factor (PDGF) [35], receptor activator of NF- $\mathrm{KB}$ ligand (RANKL), a stimulator of osteoclastogenesis, osteoprotegerin (OPG), an inhibitor of osteoclastogenesis [36], and vascular endothelial growth factor (VEGF) [37] (Fig. 2). The latter plays a crucial role, not only in the stimulation of angiogenesis during fracture repair, but also in the osteoclast recruitment, activity, and differentiation, and thus, in inducing callus remodeling during the process of endochondral ossification [38, 39].

In addition, in a recent study Romeo et al. [40] identified a novel subtype of vascular associated osteoclasts (VAOs), which are thought to be pivotal for modulating blood vessel growth in bone by directly regulating the anastomosis of type $\mathrm{H}$ vessels. Moreover, the authors demonstrated a cartilage resorbing function of endothelial cells that regulates directional bone growth by releasing proteinases such as metalloprotinease-9 [40]. These findings indicate the highly complex cellular interactions between osteogenic and endothelial cells during bone growth and regeneration.

Pericytes are vital for the stabilization and maturation of blood microvessels [41]. Tawonsawatruk et al. [42] demonstrated by injecting pericytes into the fracture site of bone defects in rats that this cell type is capable of preventing non-union formation. In addition, Supakul et al. [43] revealed that pericytes possess the ability to differentiate into osteoblasts and osteoclasts and, thus, directly contribute to the process of bone regeneration.

With a growing elderly population, the aging-associated deterioration of bone regeneration becomes of increasing importance [44]. It has been reported that the impaired fracture healing in the aged is associated with a dysfunction of the bone vascular system, resulting in a delay of angiogenesis during bone repair [44, 45]. Interestingly, aging is associated with a reduction of pericytes within the bone vascular system [46]. Therefore, it may be speculated that the dysfunction of the bone vascular system and the impaired angiogenesis during bone regeneration in the elderly, originates from the age-induced loss of pericytes.

The blood flow within the bone vasculature is thought to play a crucial role for adequate angiogenesis. In a recent study, Ramasamy et al. [47] demonstrated by intravital imaging in mice that a reduced blood flow within the bone vasculature results in an impaired angiogenesis and osteogenesis as well as a downregulation of Notch-signaling of endothelial cells. In aged mice the Notch-signaling activity of endothelial cells is also downregulated, leading to an impaired angiogenesis and osteogenesis [47]. Moreover, the blood flow within the bone vasculature can be severely disturbed by various skeletal and systemic diseases, which then also may lead to alterations of bone regeneration. These include (i) avascular necrosis of the femoral head with a decreased number of endothelial progenitor cells and blood flow interruption caused by a damaged endothelial cell membrane, subsequently resulting in ischemic injury and necrotic cell death, (ii) postmenopausal osteoporosis leading to a decreased blood vessel volume and reduced expression of pro-angiogenic markers, (iii) diabetes mellitus with an associated microangiopathy, causing vasoconstriction and a decreased blood vessel supply and (iv) atherosclerosis, resulting in oxidized lipid formation, which negatively affects bone mass by increasing anti-osteoblastogenic inflammatory cytokines and decreasing pro-osteoblastogenic Wnt ligands [48].

There is strong evidence that a disturbance in the angiogenic response after skeletal injury leads to detrimental consequences for bone regeneration [10]. Various experimental animal studies indicate that the blockade of vascularization by TNP-470, non-steroidal anti-inflammatory drugs (NSAIDs) or fumagillin, hampers fracture repair and may eventually lead to atrophic non-union formation [49-52]. Accordingly, major efforts have been undertaken to establish and validate novel vascularization strategies for the prevention of fracture healing failure. Biophysical stimulation represents a minimally invasive approach to stimulate regenerative and anabolic tissue activities. Applications, 


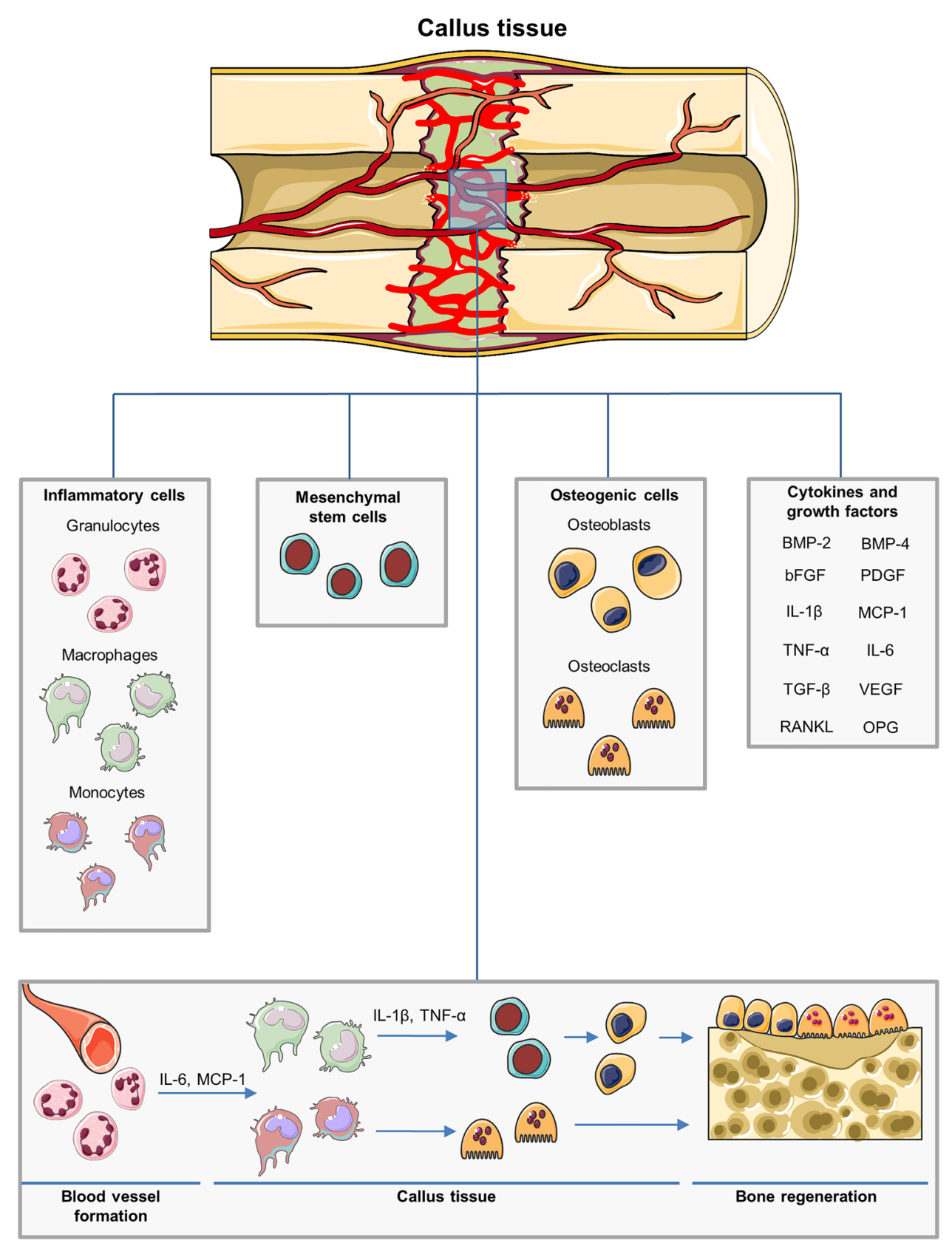

Fig. 2 Cell types and growth factors involved in fracture repair. After fracture, a richly vascularized callus tissue is formed, which provides the fracture site with cells vital for bone regeneration. Inflammatory cells, such as macrophages and granulocytes recruit further cell types to the fracture site. MSCs provide a cell pool for differentiation and proliferation. Osteoblasts and osteoclasts coordinate the process of bone growth and remodeling. Moreover, a plenitude of growth factors and mediators are expressed during bone regeneration, including BMP- 2 and BMP-4, bFGF, TNF- $\alpha$, IL-6, IL- $1 \beta$, TGF- $\beta$, monocyte chemotactic protein (MCP)-1, PDGF, RANKL, a stimulator of osteoclastogenesis, OPG, an inhibitor of osteoclastogenesis, as well as the

such as extracorporeal shock wave therapy (ESWT) [53], low-intensity pulsed ultrasound (LIPUS) [54], low frequency pulsed electromagnetic fields (ELF-PEMFs) [55], pro-angiogenic factor VEGF. After fracture, the resulting hematoma triggers an immune response. Granulocytes are among the first to arrive at the fracture site by newly formed blood vessels. These cells themselves trigger the migration of macrophages and monocytes to the callus tissue by pro-inflammatory cytokines such as IL-6 and MCP-1. Macrophages initiate the recruitment of MSCs to the fracture site by another repertoire of pro-inflammatory cytokines like IL- $1 \beta$ and TNF- $\alpha$. Furthermore, MSCs differentiate into osteoblasts, whereas monocytes differentiate into osteoclasts. Subsequently osteoblasts and osteoclasts enable callus remodeling and bone formation at the fracture site

and hyperbaric oxygenation (HBO) [56] are able to stimulate the upregulation of pro-angiogenic growth factors, and thus, the process of vascularization, osteogenesis, and bone 
formation [57-59]. Systemic pharmacological treatment represents another approach, which is feasible and easy to perform in a clinical setting. Erythropoietin (EPO), the primary regulator of erythropoiesis, has been demonstrated in a non-union mouse model to stimulate endochondral ossification and fracture repair $[60,61]$ by promoting cell proliferation, angiogenesis and bone formation [62]. The parathyroid fragment PTH 1-34 (teriparatide), the main regulator of calcium metabolism, is an additional promising compound to stimulate vascularization and bone regeneration. Teriparatide does not only enhance the migration of pro-angiogenic $\mathrm{C} 45^{+} / \mathrm{CD} 34^{+}$cells and the upregulation of VEGF-A mRNA, resulting in an increased neovascularization and cell survival [63], but also accelerates fracture healing [64] and bone formation in segmental bone defects [65]. Moreover, advanced tissue engineering approaches for bone regeneration show great potential in preclinical trials. These strategies have used combined cell populations of proangiogenic and pro-osteogenic cell lines, such as endothelial and osteoblastic cells [66, 67], to support bone regeneration in critical bone healing. Notably, the highly vascularized periosteum represents a vital prerequisite for successful fracture repair by providing the cortical blood supply [68] and serving as a source of osteogenic cells [69]. Accordingly, a plentitude of tissue engineering approaches focuses on the design of artificial periosteal substitutes. These tissue engineered constructs consist of a variety of materials including synthetic polymers [70], ceramics [71], and polysaccharides [72]. The addition of cells sheets with mesenchymal stem cells (MSCs) and endothelial cells, which mimic the physiological architecture of the native periosteum, has been used to further stimulate the angiogenic capacity of these periosteal substitutes, thus, showing great potential in promoting vascularization and fracture healing in experimental studies $[70,72]$.

\section{The vascularization paradox}

A variety of reviews emphasize the crucial role of vascularization for successful bone regeneration, however till now, no review has delineated the fact that too much vascularization may not improve fracture healing, but may even promote healing failure. Santavirta et al. [73] already reported in 1992 that delayed unions and non-unions consist of vascularized connective tissue. Several other histological studies confirmed these results and could demonstrate that nonunions are indeed considerably vascularized [74-77]. For instance, Garcia et al. [78] analyzed the fibrous callus tissue in a non-union model in mice by immunohistochemistry and detected abundant blood vessel formation within the fracture gap near the cortical bone ends (Fig. 3). In a follow-up study [79], the expression of VEGF, BMP-2, and BMP-4 was additionally analyzed in non-unions by Western blot analyses.
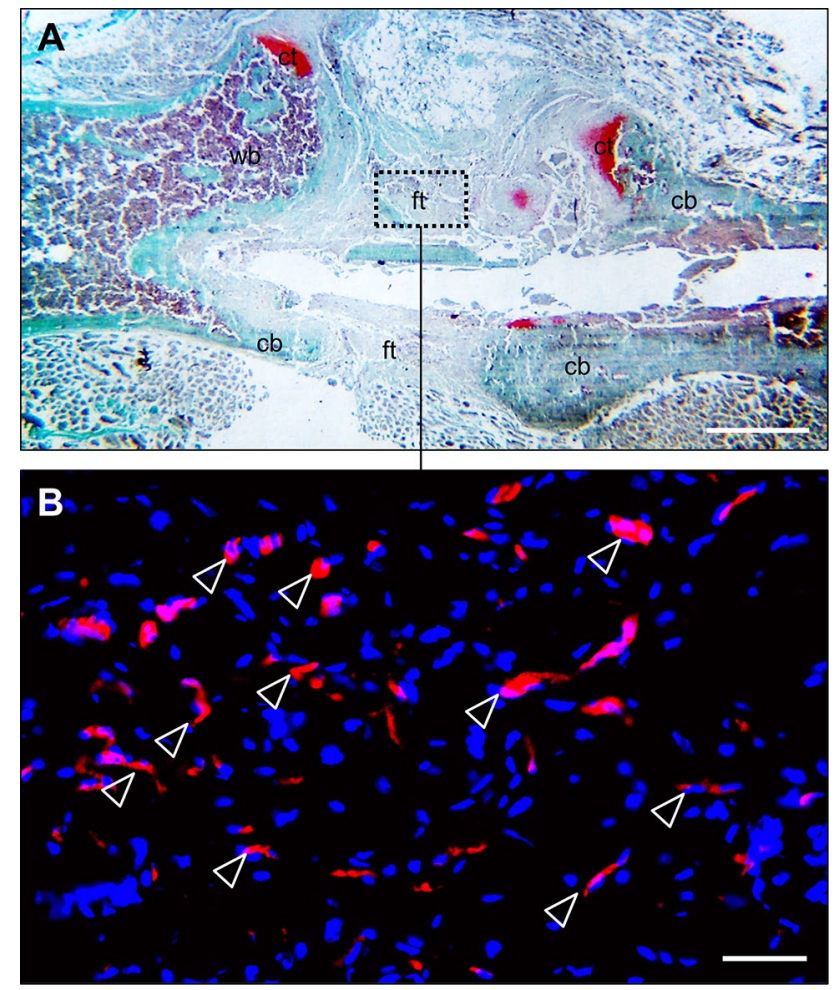

Fig. 3 Histological and immunohistochemical image of a non-union in the mouse femur. A Safranin-O staining of the callus tissue in a non-union 10 weeks after surgery according to the model described by Garcia et al. [78]. Notably, the fracture gap is filled with fibrous tissue (ft), a typical sign of atrophic non-union formation. Additionally, cartilaginous tissue (ct), woven bone (wb), and cortical bone (cb) are indicated. Scale bar: $1 \mathrm{~mm}$. B Immunohistochemical staining of CD31-positive microvessels (red) within the callus tissue in (A) (borders marked by dotted line). Cell nuclei are stained with Hoechst 33342 (blue). White arrowheads indicate abundant microvessel formation within the fibrous callus tissue at the defect site. Scale bar: $50 \mu \mathrm{m}$

Noteworthy, the intrinsic angiogenic response was sufficient for adequate vascularization during non-union formation, however, the failure of fracture healing was associated with a decreased expression of the pro-osteogenic proteins BMP-2 and BMP-4 [79]. Moreover, our own recent investigation on the effects of pantoprazole on fracture healing in aged mice demonstrated that impaired bone healing is associated with a decrease in the protein expression ratio of pro-osteogenic to pro-angiogenic growth factors, such as VEGF and cysteine rich protein(CYR)61 [80].

Eckardt et al. [81] demonstrated that the delivery of VEGF to the osteotomy gap during distraction osteogenesis could not improve blood flow, biomechanical stiffness, and bone formation of the bone regenerate. Interestingly, also the application of the VEGF inhibitor VEGF R2/F Chimera did not affect the process of bone healing [81]. These results may suggest that there are either other factors than VEGFdependent angiogenesis, which are pivotal for successful 
bone regeneration, or that angiogenesis during fracture repair is not primarily regulated by VEGF, but other growth factors including BMP-7 [82] and bFGF [83]. In line with these findings, experimental studies by Peng et al. [84, 85] and Chu et al. [86] indicate that VEGF alone is not capable of initiating the cascade of bone regeneration and an overexpression of VEGF can even impair the fracture healing process $[84,85]$. Accordingly, clinical studies by Sarahrudi et al. [87] and Weiss et al. [88] demonstrated that serum levels of VEGF are increased in patients with non-unions when compared to patients with successfully healed fractures. However, it is unclear, if the overexpression of VEGF leads to non-union formation or if the non-union formation causes its compensatory overexpression. One possible cause for the latter may be the hypoxic conditions within the callus tissue of non-unions due to an impaired functionality of the vascular network. The detection of endothelial cells within the callus tissue of non-unions is not necessarily associated with a functional vascular network, but can also represent regressing vascular structures without blood perfusion. This may also explain the reduced capacity for osteogenic proliferation and differentiation at the fracture site, because cell survival is of paramount importance under hypoxic conditions. Furthermore, the degraded vascular network may decrease the clearance of VEGF within the callus tissue. Because the control of VEGF clearance is known as crucial mechanisms to regulate VEGF activity [89], this may explain the increased VEGF levels observed in non-unions [79]. Finally, it should be considered that successful bone regeneration depends on the temporal and spatial expression patterns of growth factors [90] as well as on the ratio of pro-osteogenic to pro-angiogenic growth factors within the callus tissue, in particular the ratio of VEGF to BMP-2 and BMP-4 [79, 84, 85].

Despite the research progress during the last two decades, no ideal management for the prevention and treatment of non-union formation could be introduced into clinical practice so far. This may be due to the fact that vascularization is only one of many important factors, which are required for bone regeneration. Noteworthy, non-unions exhibit a decreased pool and delayed proliferation of MSCs as well as altered serum levels of related chemokines and growth factors, such as leptin, interleukin-6 (IL-6), platelet-derived growth factor-BB (PDGF$\mathrm{BB})$, stem cell factor (SCF), and insulin-like growth factor (IGF-1) [91]. However, the number of early and late outgrowth endothelial progenitor cells (EPCs) and their regulating pro-vasculogenic growth factors, such as angiopoietin (Ang)-1, Ang-2, stromal-derived factor-1 (SDF1), interleukin (IL)-8, VEGF, transforming growth factor$\beta$-1(TGF- $\beta-1$ ), and Dickkopf-related protein-1 (DKK-1) are not significantly affected in non-union patients [91]. These findings indicate that non-unions are, in fact, not associated with vascular degeneration and maintain the ability for both, the generation of novel blood vessels as well as angiogenesis by paracrine mechanisms. Furthermore, they emphasize the role of a mesenchymal and osteogenic cell pool defect and their related growth factors in the pathogenesis of non-union formation. Hence, it may be assumed that treatment strategies for non-unions should rather focus on the stimulation of osteogenesis than angiogenesis. This hypothesis is supported by experimental studies, which analyzed the effect of BMP-2 and VEGF co-delivery for bone regeneration. Although the sole delivery of VEGF demonstrated a stimulation of blood vessel formation, no significant increase in bone formation was detected [92-96]. In contrast, Uhrig et al. [97] could demonstrate that a transient ischemic insult and a subsequent recovery response significantly enhance BMP-2-mediated bone defect repair. This highlights the complexity of the relationship between vascularization and bone regeneration [97]. Clinical studies investigating the effect of surgical angiogenesis by the generation of arteriovenous bundles and vascularized bone grafts did not report an improved bone viability and union rate [98-100]. Although, it is well accepted in clinical practice that large bone defects of more than $6 \mathrm{~cm}$ should be supplied by vascularized bone grafts (VBGs), Allsopp et al. [99] could not confirm that VBGs are superior to non-vascularized ones (NVBGs). Accordingly, a clinical study by Schuh et al. [101] with a mean follow-up of 52 months demonstrated in diaphyseal bone reconstruction that NVBGs result in a similar radiographic and clinical outcome compared to VBGs. Moreover, NVBGs compared to VBGs tend to a lower rate of complications and revision surgery, which are mostly due to problems with wound healing related to the use of myocutaneous flaps for vascular bone grafts [101].

Even more astonishing are the findings of Orth et al. [102], who implanted hydrogels loaded with adipose tissue-derived microvascular fragments (MVF) in murine femur defects to improve vascularization and, thus, bone regeneration. However, the data of this study shows that these highly angiogenic vascularization units did not improve but even impaired the formation of new bone within the defects [102]. These findings are supported by an experimental studies of Ruehle et al. [103, 104], which evaluated the effects of BMP-2 compared to BMP-2 in combination with MVFs in bone defects with concomitant muscle loss. The results showed a decreased bending stiffness and larger areas of non-mineralized, marrow-like tissue in bone defects additionally treated with MVFs [103]. These observations imply that extensive angiogenesis and vascularization may not support, but, paradoxically, may even hamper adequate fracture repair and, therefore, aggravate non-union formation. 


\section{Future perspectives}

In the future, novel imaging technologies, such as multiphoton fluorescence microscopy $[105,106]$ and photoacoustic imaging $[107,108]$, may markedly improve our knowledge of the functionality of the microvascular networks in non-unions by the direct measurement of oxygen saturation within the callus tissue. In combination with advanced immunohistochemical staining methods and molecular biological approaches it may be possible to identify and investigate potential growth factors and mediators involved in the pathology of vascular dysfunction during non-union formation. Furthermore, the development of sophisticated multiscale simulation models, which allow to assess the influence of angiogenesis and oxygenation on fracture healing
[109-111], may help to fully understand the mechanisms of failed fracture healing and to simulate the effectiveness of specific treatment strategies. Thus, emerging treatment approaches may be able to specifically improve the functionality of these microvascular networks. Moreover, emerging treatment strategies should not only consider the stimulation of angiogenesis as a key target for bone regeneration. In fact, other factors than vascularization may substantially contribute to successful fracture repair, including mechanical stability, patients' physiological state and comorbidities as well as the availability of pro-osteogenic mediators and cells at the fracture site [1]. Thus, emerging treatment strategies should also consider these factors to improve bone regeneration. If this succeeds, also challenging cases of non-unions in clinical practice may successfully be treated and cured.
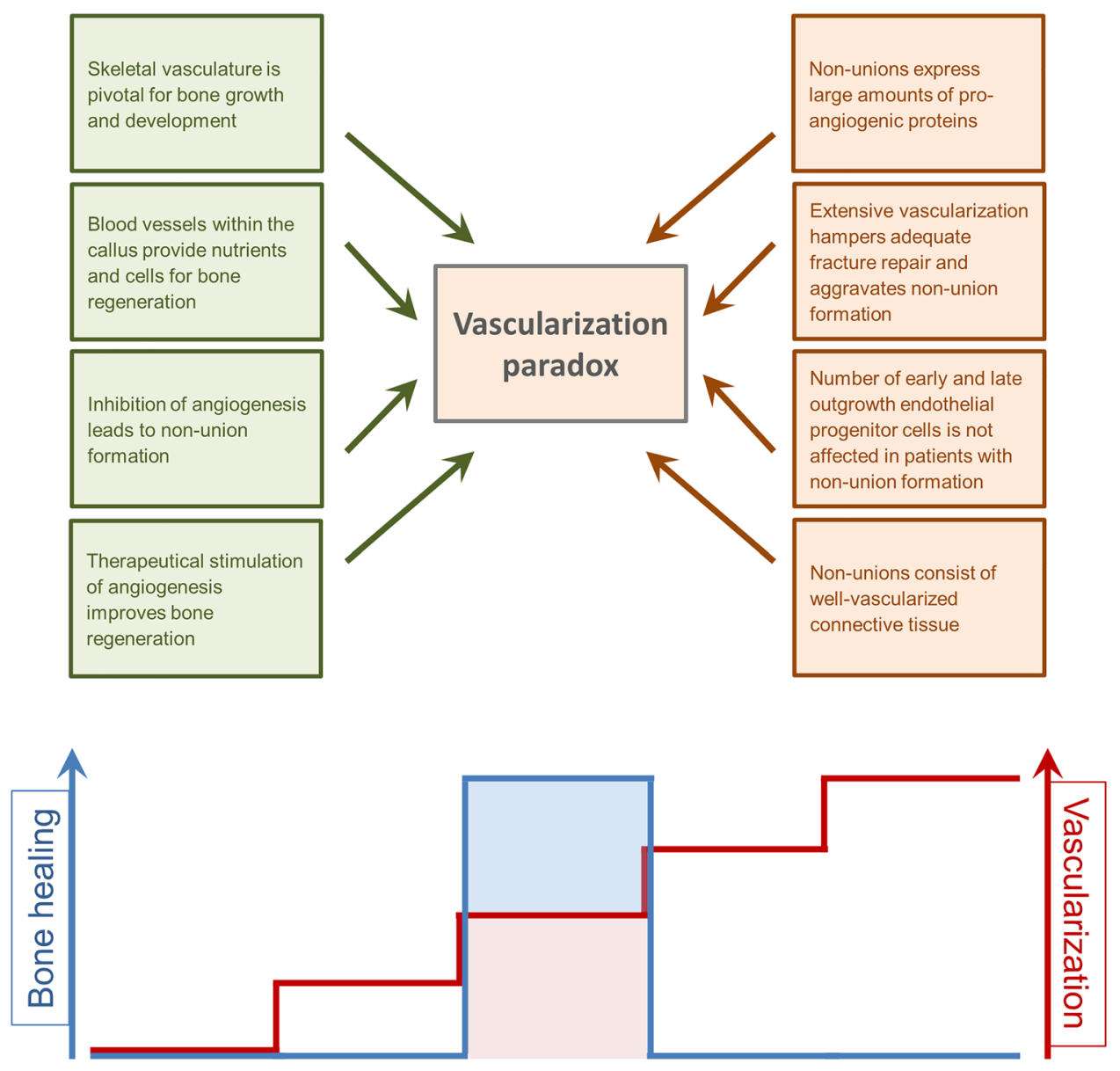

Fig. 4 Illustration of the conflicting arguments of the "vascularization paradox". Angiogenesis and vascularization are pivotal for bone growth and development as well as for the supply of nutrients and cells at the fracture site. Moreover, inhibition of angiogenesis hampers fracture repair, whereas stimulation of angiogenesis improves bone regeneration. On the other hand, non-unions demonstrate a sufficient expression of pro-angiogenic proteins. Moreover, experimental studies have demonstrated that extensive angiogenesis and vascularization hamper adequate fracture repair and aggravate non-union formation. In addition, patients with non-union formation show no alteration in the number of early and late outgrowth EPCs. Finally, the callus tissue of non-unions consists of well-vascularized connective tissue. It may be speculated that a reduced as well as an extensive vascularization impairs fracture healing and, thus, leads to non-union formation. A well-balanced temporal and spatial angiogenesis within the callus tissue, however, promotes fracture repair, resulting in successful bone healing 


\section{Conclusion}

Although, it is well accepted that the deterioration of angiogenesis and vascularization is a crucial factor for the failure of fracture healing, there is increasing evidence that this hypothesis is oversimplified. In fact, multiple studies demonstrate a considerable vascularization and even overexpression of pro-angiogenic factors within the callus tissue of non-unions. Of interest the application of highly angiogenic vascularization units in large bone defects did not improve bone formation, but, paradoxically, aggravated non-union formation [102]. This may represent a vascularization paradox in non-union formation (Fig. 4). Thus, the role of vascularization in non-union formation still remains to be determined.

Acknowledgements The authors thank Servier Medical Art for providing access to designed medical elements (https://smart.servier.com/), supporting the generation of graphical items in this publication.

Funding Open Access funding enabled and organized by Projekt DEAL.

\section{Declarations}

Conflict of interest The authors declare no conflicts of interest.

Open Access This article is licensed under a Creative Commons Attribution 4.0 International License, which permits use, sharing, adaptation, distribution and reproduction in any medium or format, as long as you give appropriate credit to the original author(s) and the source, provide a link to the Creative Commons licence, and indicate if changes were made. The images or other third party material in this article are included in the article's Creative Commons licence, unless indicated otherwise in a credit line to the material. If material is not included in the article's Creative Commons licence and your intended use is not permitted by statutory regulation or exceeds the permitted use, you will need to obtain permission directly from the copyright holder. To view a copy of this licence, visit http://creativecommons.org/licenses/by/4.0/.

\section{References}

1. Andrzejowski P, Giannoudis PV (2019) The 'diamond concept' for long bone non-union management. J Orthop Traumatol 20:21. https://doi.org/10.1186/s10195-019-0528-0

2. Fayaz HC, Giannoudis PV, Vrahas MS, Smith RM, Moran C, Pape HC, Krettek C, Jupiter JB (2011) The role of stem cells in fracture healing and nonunion. Int Orthop 35:1587-1597. https:// doi.org/10.1007/s00264-011-1338-z

3. Hak DJ, Fitzpatrick D, Bishop JA, Marsh JL, Tilp S, Schnettler R, Simpson H, Alt V (2014) Delayed union and nonunions: epidemiology, clinical issues, and financial aspects. Injury 45(Suppl 2):S3-7. https://doi.org/10.1016/j.injury.2014.04.002

4. Gustilo RB, Gruninger RP, Davis T (1987) Classification of type III (severe) open fractures relative to treatment and results. Orthopedics 10:1781-1788
5. Schmidmaier G, Capanna R, Wildemann B, Beque T, Lowenberg D (2009) Bone morphogenetic proteins in critical-size bone defects: what are the options? Injury 40:S39-S43. https://doi.org/ 10.1016/S0020-1383(09)70010-5

6. Ehnert S, Aspera-Werz RH, Ihle C, Trost M, Zirn B, Flesch I, Schroter S, Relja B, Nussler AK (2019) Smoking dependent alterations in bone formation and inflammation represent major risk factors for complications following total joint arthroplasty. J Clin Med 8:10. https://doi.org/10.3390/jem8030406

7. Ehnert S, Rinderknecht H, Aspera-Werz RH, Haussling V, Nussler AK (2020) Use of in vitro bone models to screen for altered bone metabolism, osteopathies, and fracture healing: challenges of complex models. Arch Toxicol 94:3937-3958. https://doi.org/10.1007/s00204-020-02906-z

8. Einhorn TA, Gerstenfeld LC (2015) Fracture healing: mechanisms and interventions. Nat Rev Rheumatol 11:45-54. https:// doi.org/10.1038/nrrheum.2014.164

9. Victoria G, Petrisor B, Drew B, Dick D (2009) Bone stimulation for fracture healing: what's all the fuss? Indian J Orthop 43:117-120. https://doi.org/10.4103/0019-5413.50844

10. Menger MM, Laschke MW, Orth M, Pohlemann T, Menger MD, Histing T (2020) Vascularization strategies in the prevention of non-union formation. Tissue Eng Part B Rev. https://doi.org/10. 1089/ten.TEB.2020.0111

11. Stegen S, van Gastel N, Carmeliet G (2015) Bringing new life to damaged bone: the importance of angiogenesis in bone repair and regeneration. Bone 70:19-27. https://doi.org/10.1016/j.bone. 2014.09.017

12. Kanczler JM, Oreffo RO (2008) Osteogenesis and angiogenesis: the potential for engineering bone. Eur Cell Mater 15:100-114

13. Schlundt C, Bucher CH, Tsitsilonis S, Schell H, Duda GN, Schmidt-Bleek K (2018) Clinical and research approaches to treat non-union fracture. Curr Osteoporos Rep 16:155-168. https://doi.org/10.1007/s11914-018-0432-1

14. Hankenson KD, Dishowitz M, Gray C, Schenker M (2011) Angiogenesis in bone regeneration. Injury 42:556-561. https://doi. org/10.1016/j.injury.2011.03.035

15. Huang B, Wang W, Li Q, Wang Z, Yan B, Zhang Z, Wang L, Huang M, Jia C, Lu J, Liu S, Chen H, Li M, Cai D, Jiang Y, Jin D, Bai X (2016) Osteoblasts secrete Cxc19 to regulate angiogenesis in bone. Nat Commun 7:13885. https://doi.org/10.1038/ ncomms 13885

16. Crock HV (1965) A revision of the anatomy of the arteries supplying the upper end of the human femur. J Anat 99:77-88

17. Trueta J, Harrison MH (1953) The normal vascular anatomy of the femoral head in adult man. J Bone Joint Surg Br 35-B:442461. https://doi.org/10.1302/0301-620X.35B3.442

18. Acar M, Kocherlakota KS, Murphy MM, Peyer JG, Oguro H, Inra CN, Jaiyeola C, Zhao Z, Luby-Phelps K, Morrison SJ (2015) Deep imaging of bone marrow shows non-dividing stem cells are mainly perisinusoidal. Nature 526:126-130. https:// doi.org/10.1038/nature 15250

19. Kusumbe AP, Ramasamy SK, Adams RH (2014) Coupling of angiogenesis and osteogenesis by a specific vessel subtype in bone. Nature 507:323-328. https://doi.org/10.1038/natur e13145

20. Kusumbe AP, Ramasamy SK, Starsichova A, Adams RH (2015) Sample preparation for high-resolution 3D confocal imaging of mouse skeletal tissue. Nat Protoc 10:1904-1914. https://doi.org/10.1038/nprot.2015.125

21. Roche B, David V, Vanden-Bossche A, Peyrin F, Malaval L, Vico L, Lafage-Proust MH (2012) Structure and quantification of microvascularisation within mouse long bones: what and how should we measure? Bone 50:390-399. doi:https://doi.org/10. 1016/j.bone.2011.09.051 
22. Sivaraj KK, Adams RH (2016) Blood vessel formation and function in bone. Development 143:2706-2715. https://doi.org/10. 1242/dev.136861

23. Tomlinson RE, Silva MJ (2013) Skeletal blood flow in bone repair and maintenance. Bone Res 1:311-322. https://doi.org/ 10.4248/BR201304002

24. Niedzwiedzki T, Filipowska J (2015) Bone remodeling in the context of cellular and systemic regulation: the role of osteocytes and the nervous system. J Mol Endocrinol 55:R23-36. https:// doi.org/10.1530/JME-15-0067

25. Percival CJ, Richtsmeier JT (2013) Angiogenesis and intramembranous osteogenesis. Dev Dyn 242:909-922. https://doi.org/10. 1002/dvdy. 23992

26. Chan WP, Liu YJ, Huang GS, Lin MF, Huang S, Chang YC, Jiang CC (2011) Relationship of idiopathic osteonecrosis of the femoral head to perfusion changes in the proximal femur by dynamic contrast-enhanced MRI. AJR Am J Roentgenol 196:637-643. https://doi.org/10.2214/AJR.10.4322

27. Glowacki J (1998) Angiogenesis in fracture repair. Clin Orthop Relat Res. https://doi.org/10.1097/00003086-199810001-00010

28. Bahney CS, Zondervan RL, Allison P, Theologis A, Ashley JW, Ahn J, Miclau T, Marcucio RS, Hankenson KD (2019) Cellular biology of fracture healing. J Orthop Res 37:35-50. https://doi. org/10.1002/jor.24170

29. Loi F, Cordova LA, Pajarinen J, Lin TH, Yao Z, Goodman SB (2016) Inflammation, fracture and bone repair. Bone 86:119-130. https://doi.org/10.1016/j.bone.2016.02.020

30. Carano RA, Filvaroff EH (2003) Angiogenesis and bone repair. Drug Discov Today 8:980-989. https://doi.org/10.1016/s13596446(03)02866-6

31. Barnes GL, Kostenuik PJ, Gerstenfeld LC, Einhorn TA (1999) Growth factor regulation of fracture repair. J Bone Miner Res 14:1805-1815. https://doi.org/10.1359/jbmr.1999.14.11.1805

32. Deckers MM, van Bezooijen RL, van der Horst G, Hoogendam J, van Der Bent C, Papapoulos SE, Lowik CW (2002) Bone morphogenetic proteins stimulate angiogenesis through osteoblastderived vascular endothelial growth factor A. Endocrinology 143:1545-1553. https://doi.org/10.1210/endo.143.4.8719

33. Rodan SB, Wesolowski G, Thomas KA, Yoon K, Rodan GA (1989) Effects of acidic and basic fibroblast growth factors on osteoblastic cells. Connect Tissue Res 20:283-288. https://doi. org/10.3109/03008208909023898

34. Rosier RN, O'Keefe RJ, Hicks DG (1998) The potential role of transforming growth factor beta in fracture healing. Clin Orthop Relat Res. https://doi.org/10.1097/00003086-199810001-00030

35. Mandracchia VJ, Nelson SC, Barp EA (2001) Current concepts of bone healing. Clin Podiatr Med Surg 18:55-77

36. Udagawa N, Koide M, Nakamura M, Nakamichi Y, Yamashita T, Uehara S, Kobayashi Y, Furuya Y, Yasuda H, Fukuda C, Tsuda E (2020) Osteoclast differentiation by RANKL and OPG signaling pathways. J Bone Miner Metab. https://doi.org/10.1007/ s00774-020-01162-6

37. Street J, Bao M, deGuzman L, Bunting S, Peale FV Jr, Ferrara N, Steinmetz H, Hoeffel J, Cleland JL, Daugherty A, van Bruggen N, Redmond HP, Carano RA, Filvaroff EH (2002) Vascular endothelial growth factor stimulates bone repair by promoting angiogenesis and bone turnover. Proc Natl Acad Sci U S A 99:9656-9661. https://doi.org/10.1073/pnas.152324099

38. Nakagawa M, Kaneda T, Arakawa T, Morita S, Sato T, Yomada T, Hanada K, Kumegawa M, Hakeda Y (2000) Vascular endothelial growth factor (VEGF) directly enhances osteoclastic bone resorption and survival of mature osteoclasts. FEBS Lett 473:161-164. https://doi.org/10.1016/s0014-5793(00)01520-9

39. Keramaris NC, Calori GM, Nikolaou VS, Schemitsch EH, Giannoudis PV (2008) Fracture vascularity and bone healing: a systematic review of the role of VEGF. Injury 39(Suppl 2):S4557. https://doi.org/10.1016/S0020-1383(08)70015-9

40. Romeo SG, Alawi KM, Rodrigues J, Singh A, Kusumbe AP, Ramasamy SK (2019) Endothelial proteolytic activity and interaction with non-resorbing osteoclasts mediate bone elongation. Nat Cell Biol 21:430-441. https://doi.org/10.1038/ s41556-019-0304-7

41. Crisan M, Yap S, Casteilla L, Chen CW, Corselli M, Park TS, Andriolo G, Sun B, Zheng B, Zhang L, Norotte C, Teng PN, Traas J, Schugar R, Deasy BM, Badylak S, Buhring HJ, Giacobino JP, Lazzari L, Huard J, Peault B (2008) A perivascular origin for mesenchymal stem cells in multiple human organs. Cell Stem Cell 3:301-313. https://doi.org/10.1016/j.stem.2008.07.003

42. Tawonsawatruk T, West CC, Murray IR, Soo C, Peault B, Simpson AH (2016) Adipose derived pericytes rescue fractures from a failure of healing--non-union. Sci Rep 6:22779. https://doi.org/ 10.1038/srep22779

43. Supakul S, Yao K, Ochi H, Shimada T, Hashimoto K, Sunamura S, Mabuchi Y, Tanaka M, Akazawa C, Nakamura T, Okawa A, Takeda S, Sato S (2019) Pericytes as a source of osteogenic cells in bone fracture healing. Int J Mol Sci 20:10. https://doi.org/10. 3390/ijms20051079

44. Clark D, Brazina S, Yang F, Hu D, Hsieh CL, Niemi EC, Miclau T, Nakamura MC, Marcucio R (2020) Age-related changes to macrophages are detrimental to fracture healing in mice. Aging Cell 19:e13112. https://doi.org/10.1111/acel.13112

45. Prisby RD, Ramsey MW, Behnke BJ, Dominguez II JM, Donato AJ, Allen MR, Delp MD (2007) Aging reduces skeletal blood flow, endothelium-dependent vasodilation, and NO bioavailability in rats. J Bone Miner Res 22:1280-1288. https://doi.org/10. 1359/jbmr.070415

46. Singh A, Veeriah V, Xi P, Labella R, Chen J, Romeo SG, Ramasamy SK, Kusumbe AP (2019) Angiocrine signals regulate quiescence and therapy resistance in bone metastasis. JCI Insight. https://doi.org/10.1172/jci.insight.125679

47. Ramasamy SK, Kusumbe AP, Schiller M, Zeuschner D, Bixel MG, Milia C, Gamrekelashvili J, Limbourg A, Medvinsky A, Santoro MM, Limbourg FP, Adams RH (2016) Blood flow controls bone vascular function and osteogenesis. Nat Commun. https://doi.org/10.1038/ncomms13601

48. Filipowska J, Tomaszewski KA, Niedzwiedzki L, Walocha JA, Niedzwiedzki T (2017) The role of vasculature in bone development, regeneration and proper systemic functioning. Angiogenesis 20:291-302. https://doi.org/10.1007/s10456-017-9541-1

49. Fang TD, Salim A, Xia W, Nacamuli RP, Guccione S, Song HM, Carano RA, Filvaroff EH, Bednarski MD, Giaccia AJ, Longaker MT (2005) Angiogenesis is required for successful bone induction during distraction osteogenesis. J Bone Miner Res 20:11141124. https://doi.org/10.1359/JBMR.050301

50. Fassbender M, Strobel C, Rauhe JS, Bergmann C, Schmidmaier G, Wildemann B (2011) Local inhibition of angiogenesis results in an atrophic non-union in a rat osteotomy model. Eur Cell Mater 22:1-11

51. Murnaghan M, Li G, Marsh DR (2006) Nonsteroidal anti-inflammatory drug-induced fracture nonunion: an inhibition of angiogenesis? J Bone Joint Surg Am 88(Suppl 3):140-147. https://doi. org/10.2106/JBJS.F.00454

52. Hausman MR, Schaffler MB, Majeska RJ (2001) Prevention of fracture healing in rats by an inhibitor of angiogenesis. Bone 29:560-564

53. Cacchio A, Giordano L, Colafarina O, Rompe JD, Tavernese E, Ioppolo F, Flamini S, Spacca G, Santilli V (2009) Extracorporeal shock-wave therapy compared with surgery for hypertrophic long-bone nonunions. J Bone Joint Surg Am 91:2589-2597. https://doi.org/10.2106/JBJS.H.00841 
54. Zura R, Della Rocca GJ, Mehta S, Harrison A, Brodie C, Jones J, Steen RG (2015) Treatment of chronic ( $>1$ year) fracture nonunion: heal rate in a cohort of 767 patients treated with low-intensity pulsed ultrasound (LIPUS). Injury 46:2036-2041. https:// doi.org/10.1016/j.injury.2015.05.042

55. Ehnert S, Schroter S, Aspera-Werz RH, Eisler W, Falldorf K, Ronniger M, Nussler AK (2019) Translational insights into extremely low frequency pulsed electromagnetic fields (ELFPEMFs) for bone regeneration after trauma and orthopedic surgery. J Clin Med. https://doi.org/10.3390/jcm8122028

56. Wang IC, Wen-Neng Ueng S, Yuan LJ, Tu YK, Lin SS, Wang CR, Tai CL, Wang KC (2005) Early administration of hyperbaric oxygen therapy in distraction osteogenesis--a quantitative study in New Zealand rabbits. J Trauma 58:1230-1235. https://doi.org/ 10.1097/01.ta.0000169872.38849.b0

57. Kusuyama J, Bandow K, Shamoto M, Kakimoto K, Ohnishi T, Matsuguchi T (2014) Low intensity pulsed ultrasound (LIPUS) influences the multilineage differentiation of mesenchymal stem and progenitor cell lines through ROCK-Cot/Tpl2-MEK-ERK signaling pathway. J Biol Chem 289:10330-10344. https://doi. org/10.1074/jbc.M113.546382

58. Wang CJ (2003) An overview of shock wave therapy in musculoskeletal disorders. Chang Gung Med J 26:220-232

59. Grassmann JP, Schneppendahl J, Hakimi AR, Herten M, Betsch M, Logters TT, Thelen S, Sager M, Wild M, Windolf J, Jungbluth P, Hakimi M (2015) Hyperbaric oxygen therapy improves angiogenesis and bone formation in critical sized diaphyseal defects. J Orthop Res 33:513-520. https://doi.org/10.1002/jor. 22805

60. Holstein JH, Menger MD, Scheuer C, Meier C, Culemann U, Wirbel RJ, Garcia P, Pohlemann T (2007) Erythropoietin (EPO): EPO-receptor signaling improves early endochondral ossification and mechanical strength in fracture healing. Life Sci 80:893-900. https://doi.org/10.1016/j.lfs.2006.11.023

61. Garcia P, Speidel V, Scheuer C, Laschke MW, Holstein JH, Histing T, Pohlemann T, Menger MD (2011) Low dose erythropoietin stimulates bone healing in mice. J Orthop Res 29:165-172. https://doi.org/10.1002/jor.21219

62. Holstein JH, Orth M, Scheuer C, Tami A, Becker SC, Garcia P, Histing T, Morsdorf P, Klein M, Pohlemann T, Menger MD (2011) Erythropoietin stimulates bone formation, cell proliferation, and angiogenesis in a femoral segmental defect model in mice. Bone 49:1037-1045. https://doi.org/10.1016/j.bone.2011. 08.004

63. Zaruba MM, Huber BC, Brunner S, Deindl E, David R, Fischer R, Assmann G, Herbach N, Grundmann S, Wanke R, MuellerHoecker J, Franz WM (2008) Parathyroid hormone treatment after myocardial infarction promotes cardiac repair by enhanced neovascularization and cell survival. Cardiovasc Res 77:722731. https://doi.org/10.1093/cvr/cvm080

64. Andreassen TT, Ejersted C, Oxlund H (1999) Intermittent parathyroid hormone (1-34) treatment increases callus formation and mechanical strength of healing rat fractures. J Bone Miner Res 14:960-968. https://doi.org/10.1359/jbmr.1999.14.6.960

65. Kumabe Y, Lee SY, Waki T, Iwakura T, Takahara S, Arakura M, Kuroiwa Y, Fukui T, Matsumoto T, Matsushita T, Nishida K, Kuroda R, Niikura T (2017) Triweekly administration of parathyroid hormone (1-34) accelerates bone healing in a rat refractory fracture model. BMC Musculoskelet Disord 18:545. https://doi. org/10.1186/s12891-017-1917-2

66. Yu H, Vandevord PJ, Gong W, Wu B, Song Z, Matthew HW, Wooley PH, Yang SY (2008) Promotion of osteogenesis in tissue-engineered bone by pre-seeding endothelial progenitor cellsderived endothelial cells. J Orthop Res 26:1147-1152. https:// doi.org/10.1002/jor.20609
67. Cornejo A, Sahar DE, Stephenson SM, Chang S, Nguyen S, Guda T, Wenke JC, Vasquez A, Michalek JE, Sharma R, Krishnegowda NK, Wang HT (2012) Effect of adipose tissue-derived osteogenic and endothelial cells on bone allograft osteogenesis and vascularization in critical-sized calvarial defects. Tissue Eng Part A 18:1552-1561. https://doi.org/10.1089/ten.TEA.2011.0515

68. Squier CA, Ghoneim S, Kremenak CR (1990) Ultrastructure of the periosteum from membrane bone. J Anat 171:233-239

69. Arnsdorf EJ, Jones LM, Carter DR, Jacobs CR (2009) The periosteum as a cellular source for functional tissue engineering. Tissue Eng Part A 15:2637-2642. https://doi.org/10.1089/ten. TEA.2008.0244

70. Hoffman MD, Xie C, Zhang X, Benoit DS (2013) The effect of mesenchymal stem cells delivered via hydrogel-based tissue engineered periosteum on bone allograft healing. Biomaterials 34:8887-8898. https://doi.org/10.1016/j.biomaterials.2013.08. 005

71. Chun YY, Wang JK, Tan NS, Chan PP, Tan TT, Choong C (2016) A Periosteum-Inspired 3D Hydrogel-Bioceramic Composite for Enhanced Bone Regeneration. Macromol Biosci 16:276-287. https://doi.org/10.1002/mabi.201500258

72. Romero R, Travers JK, Asbury E, Pennybaker A, Chubb L, Rose R, Ehrhart NP, Kipper MJ (2017) Combined delivery of FGF-2, TGF-beta1, and adipose-derived stem cells from an engineered periosteum to a critical-sized mouse femur defect. J Biomed Mater Res A 105:900-911. https://doi.org/10.1002/jbm.a.35965

73. Santavirta S, Konttinen YT, Nordstrom D, Makela A, Sorsa T, Hukkanen M, Rokkanen P (1992) Immunologic studies of nonunited fractures. Acta Orthop Scand 63:579-586

74. Brownlow HC, Reed A, Simpson AH (2002) The vascularity of atrophic non-unions. Injury 33:145-150. https://doi.org/10.1016/ s0020-1383(01)00153-x

75. Reed AA, Joyner CJ, Brownlow HC, Simpson AH (2002) Human atrophic fracture non-unions are not avascular. J Orthop Res 20:593-599. https://doi.org/10.1016/S0736-0266(01)00142-5

76. Reed AA, Joyner CJ, Isefuku S, Brownlow HC, Simpson AH (2003) Vascularity in a new model of atrophic nonunion. J Bone Joint Surg Br 85:604-610. https://doi.org/10.1302/0301-620x. 85b4.12944

77. Choi P, Ogilvie C, Thompson Z, Miclau T, Helms JA (2004) Cellular and molecular characterization of a murine non-union model. J Orthop Res 22:1100-1107. https://doi.org/10.1016/j. orthres.2004.03.008

78. Garcia P, Holstein JH, Maier S, Schaumloffel H, Al-Marrawi F, Hannig M, Pohlemann T, Menger MD (2008) Development of a reliable non-union model in mice. J Surg Res 147:84-91. https:// doi.org/10.1016/j.jss.2007.09.013

79. Garcia P, Pieruschka A, Klein M, Tami A, Histing T, Holstein JH, Scheuer C, Pohlemann T, Menger MD (2012) Temporal and spatial vascularization patterns of unions and nonunions: role of vascular endothelial growth factor and bone morphogenetic proteins. J Bone Joint Surg Am 94:49-58. https://doi.org/10.2106/ JBJS.J.00795

80. Menger MM, Bremer P, Scheuer C, Rollmann MF, Braun BJ, Herath SC, Orth M, Spater T, Pohlemann T, Menger MD, Histing $\mathrm{T}$ (2020) Pantoprazole impairs fracture healing in aged mice. Sci Rep 10:22376. https://doi.org/10.1038/s41598-020-79605-3

81. Eckardt H, Bundgaard KG, Christensen KS, Lind M, Hansen ES, Hvid I (2003) Effects of locally applied vascular endothelial growth factor (VEGF) and VEGF-inhibitor to the rabbit tibia during distraction osteogenesis. J Orthop Res 21:335-340. https:// doi.org/10.1016/S0736-0266(02)00159-6

82. Haubruck P, Kammerer A, Korff S, Apitz P, Xiao K, Buchler A, Biglari B, Zimmermann G, Daniel V, Schmidmaier G, Moghaddam A (2016) The treatment of nonunions with application of BMP-7 increases the expression pattern for angiogenic 
and inflammable cytokines: a matched pair analysis. J Inflamm Res 9:155-165. https://doi.org/10.2147/JIR.S110621

83. Montesano R, Vassalli JD, Baird A, Guillemin R, Orci L (1986) Basic fibroblast growth factor induces angiogenesis in vitro. Proc Natl Acad Sci U S A 83:7297-7301. https://doi.org/10.1073/ pnas.83.19.7297

84. Peng H, Wright V, Usas A, Gearhart B, Shen HC, Cummins J, Huard J (2002) Synergistic enhancement of bone formation and healing by stem cell-expressed VEGF and bone morphogenetic protein-4. J Clin Invest 110:751-759. https://doi.org/10.1172/ JCI15153

85. Peng H, Usas A, Olshanski A, Ho AM, Gearhart B, Cooper GM, Huard J (2005) VEGF improves, whereas sFlt1 inhibits, BMP2induced bone formation and bone healing through modulation of angiogenesis. J Bone Miner Res 20:2017-2027. https://doi.org/ 10.1359/JBMR.050708

86. Chu T, Liu Y, Wang Z, Zhu P, Jiao W, Wen J, Gong S (2009) Sustained vascular endothelial growth factor blockade by antivascular endothelial growth factor antibodies results in nonunion in the process of fracture healing in rabbits. J Trauma 66:1180-1183. https://doi.org/10.1097/TA.0b013e31818b4e61

87. Sarahrudi K, Thomas A, Braunsteiner T, Wolf H, Vecsei V, Aharinejad S (2009) VEGF serum concentrations in patients with long bone fractures: a comparison between impaired and normal fracture healing. J Orthop Res 27:1293-1297. https://doi.org/10. 1002/jor.20906

88. Weiss S, Zimmermann G, Pufe T, Varoga D, Henle P (2009) The systemic angiogenic response during bone healing. Arch Orthop Trauma Surg 129:989-997. https://doi.org/10.1007/ s00402-008-0777-5

89. Vempati P, Popel AS, Mac Gabhann F (2014) Extracellular regulation of VEGF: isoforms, proteolysis, and vascular patterning. Cytokine Growth Factor Rev 25:1-19. https://doi.org/10.1016/j. cytogfr.2013.11.002

90. Toosi S, Behravan J (2020) Osteogenesis and bone remodeling: A focus on growth factors and bioactive peptides. BioFactors 46:326-340. https://doi.org/10.1002/biof.1598

91. Mathieu M, Rigutto S, Ingels A, Spruyt D, Stricwant N, Kharroubi I, Albarani V, Jayankura M, Rasschaert J, Bastianelli E, Gangji V (2013) Decreased pool of mesenchymal stem cells is associated with altered chemokines serum levels in atrophic nonunion fractures. Bone 53:391-398. https://doi.org/10.1016/j. bone.2013.01.005

92. Patel ZS, Young S, Tabata Y, Jansen JA, Wong ME, Mikos AG (2008) Dual delivery of an angiogenic and an osteogenic growth factor for bone regeneration in a critical size defect model. Bone 43:931-940. https://doi.org/10.1016/j.bone.2008.06.019

93. Kaipel M, Schutzenberger S, Schultz A, Ferguson J, Slezak P, Morton TJ, Van Griensven M, Redl H (2012) BMP-2 but not VEGF or PDGF in fibrin matrix supports bone healing in a delayed-union rat model. J Orthop Res 30:1563-1569. https:// doi.org/10.1002/jor.22132

94. Kempen DH, Lu L, Heijink A, Hefferan TE, Creemers LB, Maran A, Yaszemski MJ, Dhert WJ (2009) Effect of local sequential VEGF and BMP-2 delivery on ectopic and orthotopic bone regeneration. Biomaterials 30:2816-2825. https://doi.org/10. 1016/j.biomaterials.2009.01.031

95. Geuze RE, Theyse LF, Kempen DH, Hazewinkel HA, Kraak HY, Oner FC, Dhert WJ, Alblas J (2012) A differential effect of bone morphogenetic protein-2 and vascular endothelial growth factor release timing on osteogenesis at ectopic and orthotopic sites in a large-animal model. Tissue Eng Part A 18:2052-2062. https:// doi.org/10.1089/ten.TEA.2011.0560

96. Hernandez A, Reyes R, Sanchez E, Rodriguez-Evora M, Delgado A, Evora C (2012) In vivo osteogenic response to different ratios of BMP-2 and VEGF released from a biodegradable porous system. J Biomed Mater Res A 100:2382-2391. https:// doi.org/10.1002/jbm.a.34183

97. Uhrig BA, Boerckel JD, Willett NJ, Li MT, Huebsch N, Guldberg RE (2013) Recovery from hind limb ischemia enhances rhBMP-2-mediated segmental bone defect repair in a rat composite injury model. Bone 55:410-417. https://doi.org/10.1016/j. bone.2013.04.027

98. Chung YG, Bishop AT, Giessler GA, Suzuki O, Platt JL, Pelzer M, Friedrich PF, Kremer T (2010) Surgical angiogenesis: a new approach to maintain osseous viability in xenotransplantation. Xenotransplantation 17:38-47. https://doi.org/10.1111/j.13993089.2009.00563.x

99. Allsopp BJ, Hunter-Smith DJ, Rozen WM (2016) Vascularized versus nonvascularized bone grafts: what is the evidence? Clin Orthop Relat Res 474:1319-1327. https://doi.org/10.1007/ s11999-016-4769-4

100. Hirche C, Xiong L, Heffinger C, Munzberg M, Fischer S, Kneser U, Kremer T (2017) Vascularized versus non-vascularized bone grafts in the treatment of scaphoid non-union. J Orthop Surg (Hong Kong) 25:2309499016684291. https://doi.org/10.1177/ 2309499016684291

101. Schuh R, Panotopoulos J, Puchner SE, Willegger M, Hobusch GM, Windhager R, Funovics PT (2014) Vascularised or nonvascularised autologous fibular grafting for the reconstruction of a diaphyseal bone defect after resection of a musculoskeletal tumour. Bone Joint J 96-B:1258-1263. https://doi.org/10.1302/ 0301-620X.96B9.33230

102. Orth M, Altmeyer MAB, Scheuer C, Braun BJ, Holstein JH, Eglin D, D'Este M, Histing T, Laschke MW, Pohlemann T, Menger MD (2018) Effects of locally applied adipose tissuederived microvascular fragments by thermoresponsive hydrogel on bone healing. Acta Biomater 77:201-211. https://doi.org/10. 1016/j.actbio.2018.07.029

103. Ruehle MA, Krishnan L, Vantucci CE, Wang Y, Stevens HY, Roy K, Guldberg RE, Willett NJ (2019) Effects of BMP-2 dose and delivery of microvascular fragments on healing of bone defects with concomitant volumetric muscle loss. J Orthop Res 37:553-561. https://doi.org/10.1002/jor.24225

104. Ruehle MA, Li MA, Cheng A, Krishnan L, Willett NJ, Guldberg RE (2019) Decorin-supplemented collagen hydrogels for the co-delivery of bone morphogenetic protein- 2 and microvascular fragments to a composite bone-muscle injury model with impaired vascularization. Acta Biomater 93:210-221. https://doi. org/10.1016/j.actbio.2019.01.045

105. So PT, Dong CY, Masters BR, Berland KM (2000) Two-photon excitation fluorescence microscopy. Annu Rev Biomed Eng 2:399-429. https://doi.org/10.1146/annurev.bioeng.2.1.399

106. Georgakoudi I, Rice WL, Hronik-Tupaj M, Kaplan DL (2008) Optical spectroscopy and imaging for the noninvasive evaluation of engineered tissues. Tissue Eng Part B Rev 14:321-340. https:// doi.org/10.1089/ten.teb.2008.0248

107. Zhang YS, Wang LV, Xia Y (2016) Seeing through the surface: non-invasive characterization of biomaterial-tissue interactions using photoacoustic microscopy. Ann Biomed Eng 44:649-666. https://doi.org/10.1007/s10439-015-1485-2

108. Shrestha B, DeLuna F, Anastasio MA, Ye JY, Brey EM (2020) Photoacoustic imaging in tissue engineering and regenerative medicine. Tissue Eng Part B Rev 26:79-102. https://doi.org/10. 1089/ten.TEB.2019.0296

109. Carlier A, Geris L, Bentley K, Carmeliet G, Carmeliet P, Van Oosterwyck H (2012) MOSAIC: a multiscale model of osteogenesis and sprouting angiogenesis with lateral inhibition of endothelial cells. PLoS Comput Biol 8:e1002724. https://doi. org/10.1371/journal.pcbi.1002724

110. Carlier A, van Gastel N, Geris L, Carmeliet G, Van Oosterwyck H (2014) Size does matter: an integrative in vivo-in silico 
approach for the treatment of critical size bone defects. PLoS Comput Biol 10:e1003888. https://doi.org/10.1371/journal.pcbi. 1003888

111. Carlier A, Geris L, van Gastel N, Carmeliet G, Van Oosterwyck H (2015) Oxygen as a critical determinant of bone fracture healing-a multiscale model. J Theor Biol 365:247-264. https:// doi.org/10.1016/j.jtbi.2014.10.012

Publisher's Note Springer Nature remains neutral with regard to jurisdictional claims in published maps and institutional affiliations. 